\title{
LEAD POLLUTION IN URBAN ROADSIDE ENVIRONMENTS OF DAR ES SALAAM CITY
}

\author{
GB Luilo and OC Othman \\ Department of Chemistry, University of Dar es Salaam, \\ P.O. BOX 35061, Dar es Salaam, Tanzania. \\ e-mails: kazimoto@unm.edu,othman@chem.udsm.ac.tz
}

\begin{abstract}
Lead is among the most toxic elements in nature. It is non-biodegradable and its toxicity does not change with time. Use of leaded gasoline in motor vehicles is known as the major source of lead pollution in cities in the world. Dar es Salaam, the main city of Tanzania, has thousands of cars traveling along its roads. The lead contaminating urban roadside environments of Dar es Salaam was determined. Soil and vegetation samples were collected at various distances from the road edges of the New Bagamoyo, Sam Nujoma and Mandela roads in Dar es Salaam and analyzed for lead using Atomic Absorption Spectrophotometric methods. The results show that the soils and grasses along these major highways of Dar es Salaam were contaminated with lead. The highest lead contents (152.5 ppm in soil and $35.7 \mathrm{ppm}$ in couch grass) were found in soils and vegetation within 1 to 5 meters from the road edge. The background lead levels measured at 150 meters from the road side were less than $1.2 \mathrm{ppm}$ in both soil and vegetation. The lead levels along these roads exhibited strong correlation with the average traffic density $(r$ $=0.912$ for soil and $r=0.88$ for grass). The levels of lead decreased exponentially with increasing distance away from the road. This suggests the major source of lead contamination of these areas was emissions from automobile traffic on these highways. The high levels of lead at $0-10 \mathrm{~m}$ from the roadside edge also suggest that soil and vegetation close to the roadside were a potential health hazard to both humans and animals.
\end{abstract}

\section{INTRODUCTION}

Owing to the increasing traffic volume pressures in urban areas, the environments that are closer to the highways are subject to pollution from traffic emissions. Many studies have proved beyond doubt that the urban roadside environments are polluted by heavy metals (Ndiokwere 1984, Nyangababo and Hamya 1986, Bhatia and Choudri 1991). The metal pollutants, particularly lead and zinc accumulate, in the roadside soils (Rodriguez-Flores and RodriguezCastellon 1982) and are absorbed by invertebrate macrofauna (Pizi and Josens 1995) and vegetation (Kunguru and Tole 1994, Fatoki 1996).

Lead accumulates in the environment and being non-biodegradable does not lose its toxicity with time (UNEP/WHO/ILO 1989). Its presence in the environment is undesirable as it is known to affect the growth of children. The use of leaded gasoline in cars is the major source of lead pollution in cities around the world (UNEP/WHO 1992). In the recent years the number of motor vehicles traveling on roads in Dar es Salaam City has been increasing rapidly and no study has been done so far to investigate the effect of motor vehicle emissions on the roadside environment. This paper, therefore, reports on lead pollution in the roadside soils and vegetation of Dar es Salaam City, Tanzania.

\section{MATERIALS AND METHODS \\ Sampling locations}

Sampling for soil and vegetation was conducted on the New Bagamoyo, Sam Nujoma and Mandela roads in Dar es Salaam. In total, five sampling sites were established. Two sites along the New Bagamoyo Road at Makongo and Victoria areas, one site at Café Latino area (along 
Sam Nujoma Road) and another at UbungoExternal area along the Mandela Road. Samples used for assessing background levels were collected from Lugalo-Area E about $1,000 \mathrm{~m}$ from the edge of the New Bagamoyo Road and along a side road (Fig. 1). Plant and soil samples were collected at
$1,5,15,35$ and $50 \mathrm{~m}$ from the road edges at each of the five sampling sites. Soil samples were also collected at $150 \mathrm{~m}$ from the road edge. At these $150 \mathrm{~m}$ sites no grass samples could be collected as there was very little grass left around to make up a sample.

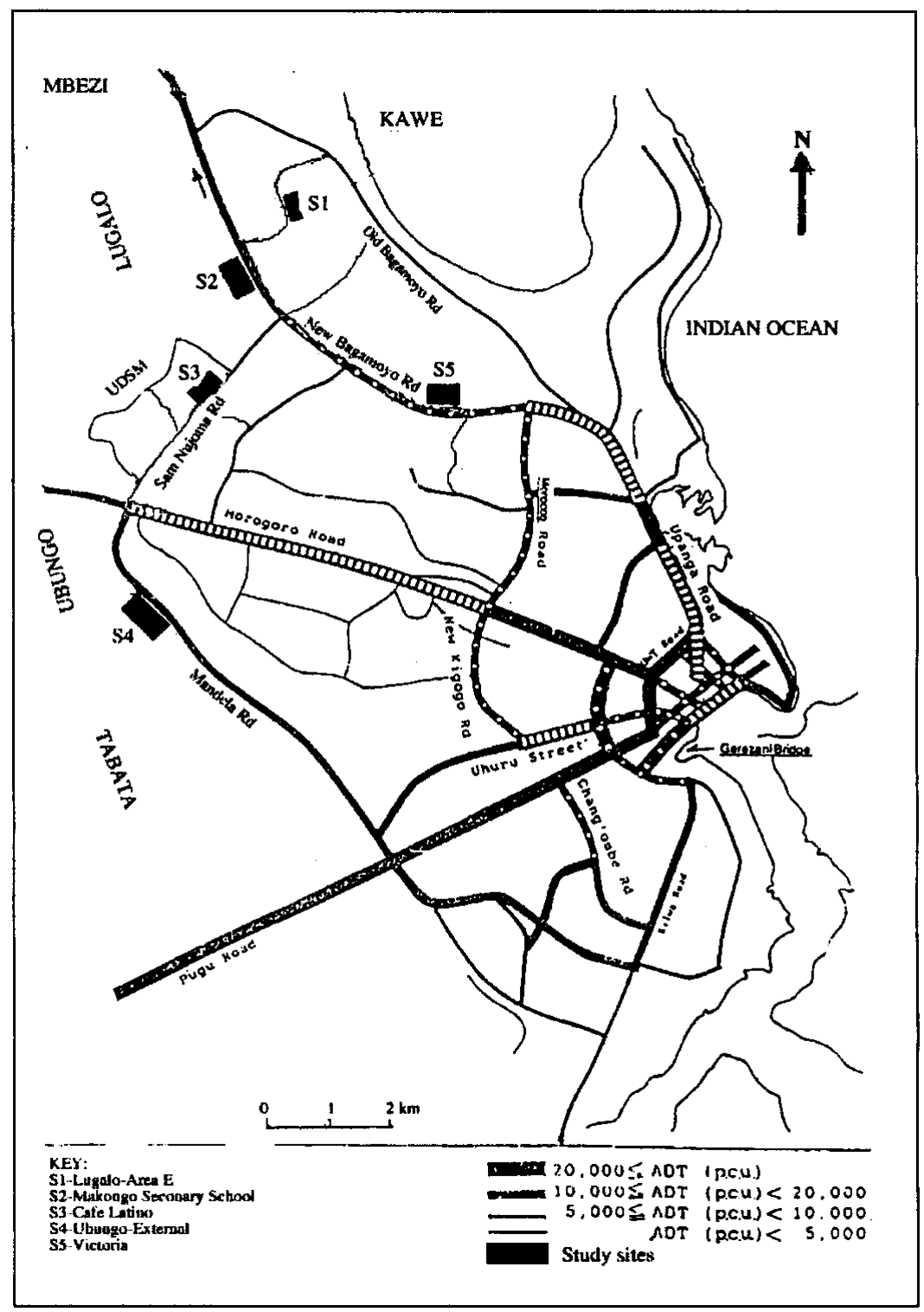

Figure 1: Map of Dar es Salaam City showing the different sampling locations along some of the major roads. 
The five sampling sites represented different average daily traffic volumes in the city as presented in Table 1. The Victoria site had the highest Average Traffic Density (ATD) of 15879 cars per day. The UbungoExternal, the Café Latino and the Makongo sites had ATDs of 12123, 9699 and 9700 cars per day respectively. Lugalo-Area E, the control site, had the lowest ATD of less than 5 cars per day. The characteristics of these sampling sites are summarized in Table 1.

Table 1: Characteristics of the sampling sites in Dar es Salaam City.

\begin{tabular}{|c|c|c|c|c|}
\hline \multirow[t]{2}{*}{ Location } & \multirow{2}{*}{$\begin{array}{c}\text { Average Daily } \\
\text { Traffic } \\
\text { (traffic density) } \\
\end{array}$} & Soil pH & $\begin{array}{c}\text { Soil organi } \\
\text { matter }\end{array}$ & $\begin{array}{l}\text { Soil conductivity } \\
(\mu \mathrm{S} / \mathrm{cm})\end{array}$ \\
\hline & & \multicolumn{3}{|c|}{ (no. of samples per site $=6$ ) } \\
\hline $\begin{array}{l}\text { Lugalo-Area E (far off } \\
\text { New Bagamoyo road) }\end{array}$ & $<5$ & $8.4 \pm 0.4$ & $5.00 \pm 0.44$ & $421.3 \pm 22.0$ \\
\hline $\begin{array}{l}\text { Makongo area (along } \mathrm{Ne} \\
\text { Bagamoyo road) }\end{array}$ & 9699 & $7.9 \pm 0.1$ & $5.98 \pm 0.45$ & $292.8 \pm 32.4$ \\
\hline $\begin{array}{l}\text { Café Latino area (along } \\
\text { Sam Nujoma road) }\end{array}$ & 9700 & $7.5 \pm 0.3$ & $6.10 \pm 0.80$ & $161.3 \pm 9.7$ \\
\hline $\begin{array}{l}\text { Ubungo-External (alon! } \\
\text { Mandela road) }\end{array}$ & 12123 & $7.4 \pm 0.2$ & $3.54 \pm 0.85$ & $134.8 \pm 40.5$ \\
\hline $\begin{array}{l}\text { Victoria area (along New } \\
\text { Bagamoyo road) }\end{array}$ & 15879 & $7.8 \pm 0.1$ & $7.20 \pm 0.80$ & $153.8 \pm 12.8$ \\
\hline
\end{tabular}

\section{METHODS}

Soil samples were collected at a depth of 0 $5 \mathrm{~cm}$ from the surface. Ten soil samples from different points at one sampling location were collected and a composite sample prepared for that location. The plant material, Couch grass (Cynodon dactylon), was also sampled simultaneously at each place where soil was sampled. After collection the composite soil samples and composite plant samples were taken to the laboratory for further treatment and analysis. About $20 \mathrm{~g}$ of air-dried soil and $5 \mathrm{~g}$ of plant samples (charred at $450^{\circ} \mathrm{C}$ for 30 minutes) were digested in $50 \mathrm{~cm}^{3}$ of $4 \mathrm{M} \mathrm{HCl}$ and left to stand for 12 hours. The samples were then filtered and the filtrates diluted to the mark in $250 \mathrm{~cm}^{3}$ volumetric flasks. The lead in the solutions of both the soil and plant samples was analyzed by Atomic Absorption Spectrophotometry (PerkinElmer, model AAnalyst 300).

\section{RESULTS AND DISCUSSION}

Analysis of lead contamination in soil and Couch grass (Cynodon dactylon) samples showed that there is substantial contamination in both ecological materials at all the sites next to highways. The mean lead contents (ppm) in the soils and Couch grass at the different sites are presented in Table 2. The mean lead contents at different distances from the road edge are presented in figs. 2 - 3. 
Luilo and Othman - Lead pollution in urban roadside environment ...

Table 2: $\quad$ Mean lead content ( $\mathrm{ppm})$ in soil and Couch grass at various locations in Dar es Salaam City.

\begin{tabular}{lccc}
\hline \multicolumn{1}{c}{ Location } & $\begin{array}{c}\text { Average Daily } \\
\text { Traffic }\end{array}$ & Soil & Couch grass \\
\cline { 3 - 4 } & $<5$ & $9.27 \pm 0.23$ & $1.15 \pm 0.64$ \\
\hline $\begin{array}{l}\text { Lugalo-Area E (far off } \\
\text { New Bagamoyo road) }\end{array}$ & & $18.56 \pm 6.87$ & $4.88 \pm 2.01$ \\
$\begin{array}{l}\text { Makongo area (along New } \\
\text { Bagamoyo road) }\end{array}$ & 9699 & $22.69 \pm 7.87$ & $5.88 \pm 1.40$ \\
$\begin{array}{l}\text { Café Latino area (along } \\
\text { Sam Nujoma road) }\end{array}$ & 9700 & $35.09 \pm 16.22$ & $13.84 \pm 5.70$ \\
$\begin{array}{l}\text { Ubungo-External (along } \\
\text { Mandela road) }\end{array}$ & 12123 & $45.92 \pm 22.06$ & $17.73 \pm 3.54$ \\
$\begin{array}{l}\text { Victoria area (along New } \\
\text { Bagamoyo road) }\end{array}$ & 15879 & 20 & 1.0 \\
\hline $\begin{array}{l}\text { Average natural mean } \\
\text { lead levels (Ward 1995) }\end{array}$ & & & \\
\hline
\end{tabular}

It is evident from these results that roadside soil and grass are contaminated with lead. We note also that the mean lead levels in the soil and grass samples exceed the average natural trace metal contents in soil and grass of $20 \mathrm{ppm}$ and $1 \mathrm{ppm}$, respectively (Ward 1995). The roadside soil and grass from Victoria site had the highest levels of contamination of lead while those from Lugalo area $\mathrm{E}$ had the least (Table 2). There is also a large difference between the mean lead levels in soil and that in grass at each site. This is probably because the heavy metal levels in plants are determined not only by the concentration in the soil but also by the physico-chemical properties of the soil like $\mathrm{pH}$, Cation Exchange Capacity (CEC), electrical conductivity (EC) and organic matter content of the soil (Alloway and Ayres 1993). The observed difference indicates that only a fraction of the total lead content in the roadside soil was taken up by the plants.
The influence of road traffic emission on the roadside environment was evaluated by considering variation in the levels of lead in soil and grass with respect to increasing distance away from the road edge. There was substantial contamination with lead in both soil and grass collected at a distance of $1 \mathrm{~m}$ to $5 \mathrm{~m}$ from the road edge. It was also observed that the lead content of soil from Victoria site $(1-5 \mathrm{~m})$ had the highest level of lead $(150 \mathrm{ppm})$ which decreased rapidly to $50 \mathrm{ppm}$ at the $15 \mathrm{~m}$ location whereas at the Lugalo Area E site the lead levels remained more or less constant regardless of the distance from the road. The lead levels in roadside soil at each site decreased exponentially with distance from the road edge (Fig. 2). These two observations provide suggest that passing motor vehicles on the roads were responsible and were the point sources of lead to the roadside soils and grass. 


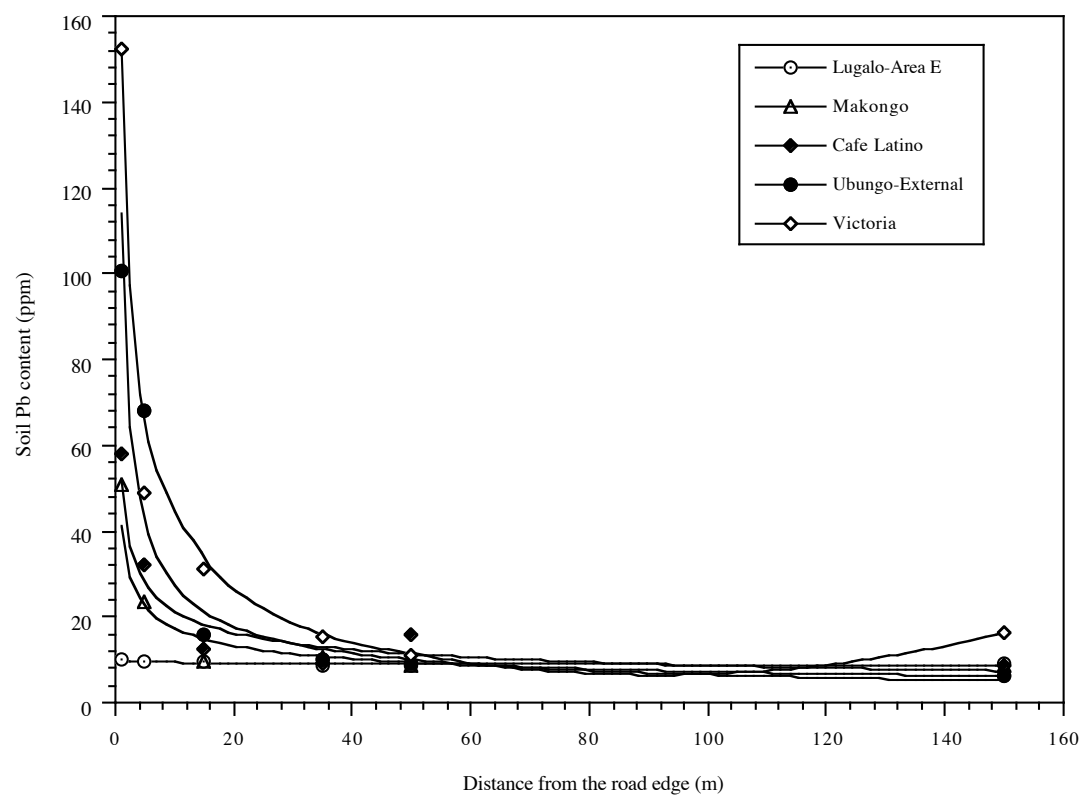

Figure 2: Mean lead content in soils at different distances from the road edge at the five sampling locations.

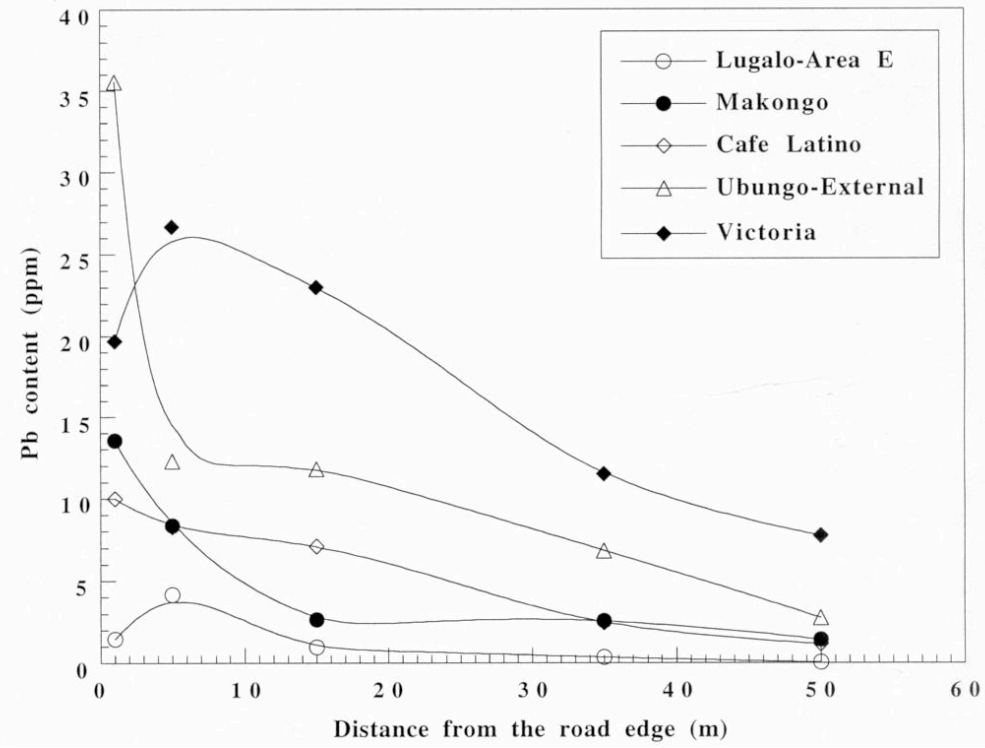

Figure 3: Mean lead content in Couch grass at various distances from the road edge at the different sampling locations. 
There was slight increase in the lead content in soil from the $150 \mathrm{~m}$ sites as compared to the $50 \mathrm{~m}$ sites. Similar observation has also been reported (Ndiokwere 1984, Ferreti et al. 1995, Bhatia and Choudhri 1995 and Naszadi et al. 2000). Such an increase in metal content at a distance beyond $35 \mathrm{~m}$ off the road edge is usually attributed to geological and/or biological decomposition of leaf litters as discussed by Lagerwerff and Specht (1970) and Wade et al. (1980). In general, therefore it was observed that the lead contents in soil decreased exponentially with distance from the road edge and increased with average daily traffic volume.

It was also observed that the lead contents in roadside vegetation (Couch grass) increased with average daily traffic volume (Table 2) and decreased exponentially with distance from the road edge (fig. 3) for the Makongo and Ubungo-External sites only. The results for the Victoria and Café Latino sites did not show this property. This may be due to the differences in the physico-chemical properties of the soils, which influence availability of nutrients for uptake by plants. The lower lead level at the $1 \mathrm{~m}$ site at Victoria and elevated levels at $5 \mathrm{~m}$ at Lugalo Area E could be attributed to these facts. The growth stage and physiology of the plants also indirectly affect the metal contents in the plants (Xian 1989). In this study plants were sampled irrespective of their growth stage and therefore there is a possibility that the relative proportion of mature and young cynodon grass in the composite samples were different from one sampling point to another. This could affect the exponential decrease in lead levels with distance from the road edge. In general, roadside grass in Dar es Salaam was also contaminated with lead and the average lead contents in roadside vegetation increased with increase in average daily traffic volume. Repeated measures analysis of variance test showed that there was extremely significant variation (ANOVA, $\mathrm{F}=7.046, \mathrm{p}=0.001$ ) in soil-lead contents among the sites. In the case of grass-lead contents, the test showed that there was also significant variation in lead contents (ANOVA, F = 3.897, $\mathrm{p}=$ 0.013 ) among the sites. There was also a strong correlation between soil lead contents $(\mathrm{r}=0.913)$ and plant lead contents $(\mathrm{r}=$ 0.880 ) and the average daily traffic density. From Table 1 it is evident that Makongo (ATD - 9699 cars/day) and Café Latino (ATD - 9700 cars/day) had about the same content of lead in their soil and vegetation. Similar lead contamination of roadside soils had been reported elsewhere (Ndiokwere 1984, Nyangababo and Hamya 1986, Ferreti et al. 1995). These results suggest that the grasses and soils alongside Dar es Salaam roads were contaminated with lead and that traffic emissions are the major source of the lead to the soil and vegetation in the areas closer to highways.

\section{CONCLUSION}

The current traffic density in Dar es Salaam has significant impact on the soils and plants along its major roads. Lead is being deposited onto roadside soils and on vegetation along these roads. The maximum lead level in soil (150 ppm) was found at Victoria close to the road edge and the maximum lead level in grass (35 ppm) was found at the Ubungo External site. The lead levels in soils alongside roads show an exponential decrease with respect to distance away from the road edge. Horticultural activities taking place on the roadside soils in the city are therefore subjected to lead contamination. The Cynodon grasses are also a potential source of animal feed in the city. Such use might pose health risks not only to domesticated animals but also to man via the food chain. Therefore, it is only safe to use grass for feeding animals or to eat vegetables grown at distances more than 50 meters from the edge of highways of Dar es Salaam City. Because of possible heavy metal contamination there is need for conducting further monitoring of the quality of foods grown or prepared near and alongside highways especially fast-foods, animal feeds and vegetable plants. 


\section{REFERENCES}

Alloway BJ and Ayres DC 1993 Chemical Principles of Environmental Pollution Blackie Academic \& Professionals Glassgow.

Bhatia I and Choudri GN 1991 Impact of automobile effusion on plant and soil, Int. J. Ecol. and Env. Sc. 17: 121-127

Fatoki OS 1996 Trace zinc and copper concentration in roadside surface soils and vegetation measurement of local atmospheric pollution in Alice, South Africa, Env. Int. 22: 759-762

Ferretti M, Cenni E, Bussotti $F$ and Batistoni P 1995 Vehicle-induced lead and cadmium contamination of roadside soil and plants in Italy, Chem. Ecol. 11: 213-228

Kunguru K and Tole PM 1994 Contamination of soils, maize, wheat, and milk with lead from motor vehicle emissions in Uasin Gishu District, Kenya. Disc. Innov. 3: 261-264

Lagerweff JV and Specht WA 1970 Contamination of nroadside soils and vegetation with cadmium, nickel, lead and zinc Env. Sci. Technol. 4: $583-$ 586.

Naszradi T, Koles P and Badacsonyi A 2000 Temporal and spatial distribution of heavy metal content in the soil of an alfalfa (Medicago sativa) field close to the M3 motorway (Hungary) In: Burghardt $\mathrm{W}$ and Dornauf $\mathrm{C}$ (eds) Proceedings of the First International Conference on soils of Urban Industrial traffic and Mining Areas Essen 955 960.

Ndiokwere CL 1984 A study of heavy metal pollution from motor vehicle emissions and its effects on roadside soil, vegetation and crops in Nigeria. Env. Pollut. (Series B) 7: 35-42

Nyangababo JT and Hamya JW 1986 The deposition of lead, cadmium, zinc and copper from motor traffic on Brachiaria enimi and soil along a major Bombo road to Kampala City Int. J. Env. Stud. 27: 115-119

Pizi V and Josens G 1995 The influence of traffic pollution on earthworms and their heavy metal contents in an urban ecosystem Pedobiol. 39: 442-453

Rodriguez-Flores $M$ and RodriguezCastellon E 1982 Lead and cadmium levels in soil and plants near highways and their correlation with traffic density Environ. Pollut. (Series B) 4: 281-290

UNEP/WHO 1992 Air Pollution in MegaCities of the World United Nations Environment Programme (UNEP) publications, New York.

UNEP/WHO/ILO 1989 Environmental Health Criteria No. 85: Lead Environmental Aspects World Health Organization Geneva.

Wade KJ, Flanagan JT, Currie A and Curtis DJ 1980 The deposition of lead and zinc from traffic pollution on two roadside shrubs Environ. Pollut. 1: 87 -93.

Ward NI 1995 Trace elements In: Fifield FW. and Haines P.J (eds.) Environmental analytical chemistry Blackie Academic \& Professionals London, 321 - 351.

Xian X 1989 Effects of chemical forms of cadmium, zinc and lead in polluted soils and their uptake by cabbage plants. Plant. Soil, 131257 - 264. 